\title{
RANCANG BANGUN SISTEM BASIS DATA UNTUK MENUNJANG PENGELOLAAN PERIKANAN TUNA CAKALANG DAN TONGKOL DI PERAIRAN NATUNA
}

\author{
Gilar Budi Pratama, Tri Wiji Nurani, dan Ronny Irawan Wahju \\ Departemen Pemanfaatan Sumberdaya Perikanan, Institut Pertanian Bogor \\ Kampus IPB, Jl. Raya Dramaga, Babakan, Dramaga, Bogor, Jawa Barat 16680 \\ E-mail: triwiji@hotmail.com
}

\begin{abstract}
ABSTRAK
Salah satu upaya pemerintah dalam meningkatkan akurasi data hasil tangkapan adalah dengan meluncurkan program sistem basis data bernama Satu Data. Namun pendataan dengan sistem tersebut masih belum mencapai tempat pendaratan ikan yang kecil, salah satunya di Natuna. Pendaratan ikan di Natuna dilakukan di dermaga-dermaga kecil yang tersebar di sepanjang pantai. Hal ini akan menyebabkan data hasil tangkapan tidak tercatat dan terintegrasi dengan baik. Tujuan penelitian ini yaitu mengidentifikasi tempat-tempat pendaratan ikan nelayan kecil di sekitar Sentra Kelautan dan Perikanan Terpadu Natuna, melakukan penilaian pendataan yang dilakukan dermaga-dermaga kecil di daerah Bunguran Timur serta kemudian menyusun dan mengimplementasikan sebuah sistem database perikanan berbasis website yang dapat digunakan untuk melakukan pendataan hasil tangkapan. Data yang digunakan adalah data dermaga pendaratan ikan di Bunguran Timur, mekanisme pendataan hasil tangkapan yang sekarang dilakukan dan produksi perikanan di dermaga pendaratan ikan. Metode analisis yang digunakan adalah deskriptif, deskriptif komparatif dan pengembangan sistem informasi. Analisis deskriptif digunakan untuk menggambarkan dermaga-dermaga pendaratan ikan dan mekanisme pendataan hasil tangkapan, sedangkan deskriptif komparatif untuk membandingkan metode pendataan hasil tangkapan yang digunakan di setiap dermaga dengan Sentra Kelautan dan Perikanan Terpadu di Natuna. Pengembangan sistem informasi bertujuan menghasilkan sistem pendataan hasil tangkapan yang efektif berdasarkan kebutuhan informasi. Hasil dari penelitian ini adalah sebuah sistem basis data yang digunakan sebagai sistem pendataan hasil tangkapan ikan berbasis online yang bernama Nelayanku Heroku. Nelayanku Heroku memiliki tiga menu utama berupa menu dashboard, menu nelayan dan menu data tangkapan.
\end{abstract}

Kata kunci: Dermaga Pendaratan Ikan; Hasil tangkapan; Integrasi Data; Sistem Informasi.

\section{DESIGN DATABASE SYSTEM TO SUPPORT THE MANAGEMENT OF FISHERIES OF TUNA CAKALANG AND TONGKOL IN NATUNA}

\begin{abstract}
One of the government's efforts to improve the accuracy of catch data is by launching a database program called Satu Data. However the program is not yet applied on small fish landings, like in Natuna. Fish landings in Natuna are spread in small fish landings throughout the coastline. Thus, resulting in poor and lacking data that could yield in unrecorded and incomplete record. The purposes of this research are to identify fish landing areas for small-scale fisheries around Sentra Kelautan dan Perikanan Terpadu Natuna, to authenticate the data input carried out in small fishing docks in Bunguran Timur and to establish and implement web-based database fishery system which can be used to input marine catch data. Data needed are fish catch data of small fishing landing place in Bunguran Timur, current input methods used, and fisheries production of the docks. Method analysis used are descriptive, descriptive-comparative, and advancement of the information system. Descriptive analysis is used to represent the fishing docks and the mechanism of catch data recording themselves while the descriptive-comparative method is used to compare catch data input method in each Sentra Kelautan dan Perikanan Terpadu fishing dock in Natuna. The purpose of advancing the information system is to yield an effective catch data input system based on necessary information. The result of this research is an online database program operated to input total marine catch named as Nelayanku Heroku. There are three main menu in Nelayanku Heroku such as dashboard, fishermen and catch data menu.
\end{abstract}

Key words: Fish Landings; Marine Catch Data; Iata Integration; Information System.

\section{PENDAHULUAN}

Potensi ikan pelagis di Natuna mencapai 327.976 ton dengan produksi sebesar 99.037 ton, dengan tangkapan dominan adalah tongkol krie (Auxis thazard) mencapai $1,88 \%$ dari total produksi perikanan tangkap di Natuna (KKP, 2016). Potensi sumber daya ikan yang besar mendorong masyarakat Natuna menggantungkan hidup dengan menjadi nelayan. Terdapat sekitar 20.571 jiwa penduduk Natuna hidupnya tergantung pada lapangan usaha perikanan (BPS, 2017). Nelayan di Kabupaten Natuna memiliki kebiasaan untuk mendaratkan dan menjual ikan hasil tangkapan di dermaga-dermaga kecil yang tersebar di sepanjang Pantai Natuna. Pembangunan
Sentra Kelautan dan Perikanan Terpadu (SKPT) di Selat Lampa berdasarkan Inpres No. 7 Tahun 2016 diharapkan dapat menghimpun kapal-kapal penangkapan ikan untuk mendaratkan ikan di lokasi yang telah ditetapkan oleh pemerintah (Zulham et al., 2017). Adanya ketergantungan nelayan terhadap tauke akibat hutang nelayan kepada tauke yang memaksa nelayan mendaratkan dan menjual ikan langsung kepada tauke di dermaga-dermaga kecil dibandingkan di SKPT (Ismail et al., 2018).

Pendaratan ikan hasil tangkapan yang dilakukan di dermaga-dermaga kecil yang tersebar di sepanjang Pantai Natuna akan menyebabkan data hasil tangkapan tidak tercatat baik, hal ini akan menyebabkan bias data produksi perikanan tangkap 
yang ada di Natuna. Penting bagi pemerintah untuk mendapatkan data dan informasi yang tepat berkaitan dengan pendataan jumlah hasil tangkapan yang didaratkan di suatu wilayah. Salah satu upaya Kementerian Kelautan dan Perikanan (KKP) untuk mendapatkan data jumlah hasil tangkapan yang di daratkan di pelabuhan perikanan secara valid adalah dengan meluncurkan sebuah program unggulan bernama "Satu Data" pada tahun 2016. Salah satu fasilitas yang ada di dalam Satu Data adalah sistem pendataan produksi perikanan berbasis website (KKP, 2019). Sistem ini telah dilakukan oleh beberapa pelabuhan perikanan, namun belum terlaksana di tempat pendaratan ikan skala kecil seperti yang ada di Natuna.

Perlu adanya sistem baru dalam pendataan hasil tangkapan ikan di dermaga-dermaga kecil di Natuna yang lebih mudah dilakukan dan dapat langsung terintegrasi ke pusat pendataan. Maka tujuan penelitian ini adalah mengidentifikasi tempat-tempat pendaratan ikan nelayan kecil di sekitar SKPT Natuna, melakukan penilaian pendataan yang dilakukan dermaga-dermaga kecil di daerah Bunguran Timur dan kemudian menyusun dan mengimplementasikan sebuah sistem database perikanan berbasis website yang dapat digunakan untuk melakukan pendataan hasil tangkapan. Menurut Waljiyanto (2003), database adalah suatu kumpulan data dan informasi yang tersimpan di dalam suatu perangkat secara sistematik sehingga dapat diperiksa dan diolah menggunakan suatu program komputer. Sedangkan sistem database berbasis website adalah sebuah sistem informasi data daring yang terdiri dari perangkat keras (hardware) dan perangkat lunak (software), pengelolaan pelayanan serta penyedia informasi yang dapat diakses melalui suatu perangkat komputer (Andrasto, 2013). Langkah awal dalam merancang sistem database pendataan tersebut adalah dengan melakukan identifikasi tempat pendaratan atau dermaga mana saja yang menjadi tempat pendaratan ikan hasil tangkapan nelayan. Kemudian melakukan pendeskripsian sekaligus penilaian terhadap proses pendataan yang ada untuk melihat apakah praktik pendataan yang ada telah tepat sehingga data yang dihasilkan pun valid. Deskripsi dan penilaian terhadap praktik pendataan kemudian dijadikan sebagai dasar penyusunan database perikanan berbasis website yang akan mempermudah proses pendataan dan mengintegrasikan hasil pendataan ke pusat informasi.

\section{METODE}

Data penelitian ini terbagi menjadi data sekunder dan data primer. Data sekunder diperoleh dari Dinas Kelautan dan Perikanan (DKP) Natuna, sedangkan data primer diperoleh melalui pengamatan lapang dan wawancara dengan kuisioner. Lokasi pendaratan yang disurvei adalah dermaga yang tersebar di Bunguran Timur dengan responden yang ditentukan melalui teknik accidental sampling. Menurut Juliandi et al. (2014), accidental sampling adalah teknik pengambilan sampel dimana sampel tidak ditentukan terlebih dahulu, namun langsung mengumpulkan data dari sampel yang ditemui secara tidak sengaja dan dianggap sesuai sebagai sumber data. Data hasil tangkapan berasal dari para nelayan yang melakukan pendaratan ikan di dermaga kecil Bunguran Timur. Metode pengumpulan data hasil tangkapan dilakukan dengan mencatat jenis hasil tangkapan dan bobotnya ke dalam logbook. Total terdapat 7 dermaga dengan responden berjumlah 53 orang yang terdiri dari 48 nelayan dan 2 orang petugas pendataan hasil tangkapan dari DKP, serta 3 orang petugas pendataan hasil tangkapan dari SKPT. Penilaian mekanisme pendataan hasil tangkapan diperoleh melalui pengisian kuisioner dengan wawancara dan survei langsung terhadap petugas pendataan yang ada di dermaga kecil dan SKPT.

Metode analisis data yang digunakan adalah analisis deskriptif, analisis deskriptif komparatif dan pengembangan sistem informasi. Analisis deskriptif digunakan untuk memberikan gambaran tempat yang dijadikan sebagai pangkalan kecil pendaratan ikan di perairan Natuna. Selanjutnya adalah analisis deskriptif komparatif yaitu dengan membandingkan mekanisme pendataan, petugas pendataan dan kegunaan dari data hasil tangkapan yang dilakukan di tempat-tempat pendaratan kecil dan SKPT Natuna. Metode analisis pengembangan sistem informasi adalah suatu cara penyelesaian permasalahan di dalam suatu manajemen data dan informasi dengan melakukan identifikasi kebutuhan informasi yang ada pada suatu sistem sehingga dihasilkan suatu operasi sistem informasi atau aplikasi yang efektif (Pradipta, 2010). Menurut Handoyo (2011) terdapat lima tahapan dalam merancang dan membangun aplikasi berbasis website menggunakan metode pengembangan sistem informasi, yaitu perencanaan sistem informasi, analisis sistem informasi, perancangan sistem informasi, implementasi sistem informasi dan validasi sistem informasi.

\section{Perencanaan Sistem Infomasi}

Pada tahap ini dilakukan pengumpulan data dan informasi terkait sistem, kemudian dari sistem tersebut diuraikan menjadi subsistem-subsistem. Dari subsistem yang ada kemudian dipilih subsistem yang akan digunakan dalam merancang web basis data dan digunakan sebagai menu pada sistem. Database berbasis website dirancang dengan tiga menu utama yaitu menu halaman utama dashboard, nelayan dan data tangkapan. Menu nelayan dan data tangkapan memiliki submenu dimana kategori pilihan dalam submenu tersebut didapatkan melalui studi pustaka Badan Statistik Kelautan dan Perikanan Indonesia mengenai jenis ikan tongkol, cakalang, dan tuna serta mengenai jenis-jenis alat tangkap dan ukuran kapal yang digunakan di perairan Natuna.

\section{Analisis Sistem Informasi}

Tahap analisis sistem informasi terbagi menjadi 3 bagian yaitu analisis kebutuhan informasi, formulasi permasalahan dan identifikasi sistem informasi seperti yang dijelaskan di bawah ini: 
a. Analisis kebutuhan informasi

Pada tahap ini dilakukan pencarian secara selektif kebutuhan informasi masing-masing pelaku dalam sistem perikanan tangkap tuna, cakalang dan tongkol (TCT) di Natuna. Dalam menentukan kebutuhan informasi dilakukan dengan metode wawancara kepada pelaku-pelaku sistem dan pengamatan secara langsung dilapangan. Menurut Setiawan et al. (2016), analisis kebutuhan informasi merupakan tahap awal dan utama untuk mendapatkan informasi dan data yang dibutuhkan pelaku sistem di dalam suatu perangkat lunak.

a. Formulasi permasalahan

Tahap ini dilakukan perumusan permasalahan yang terdapat dalam pendataan perikanan TCT. Metode untuk merumuskan permasalahan dilakukan dengan pengamatan secara langsung di lapangan serta menggunakan metode wawancara dengan pelaku yang ada dalam ruang lingkup sistem.

b. Identifikasi sistem informasi

Identifikasi sistem informasi dibuat untuk mendapatkan gambaran secara garis besar terhadap sistem informasi. Gambaran sistem informasi ini dilakukan dengan pembuatan diagram sebab-akibat dan diagram input-output. Diagram sebab akibat ini bertujuan untuk menggambarkan hubungan antar komponen di dalam sistem informasi sedangkan diagram inputoutput digunakan untuk menggambarkan masukan dan keluaran serta kontrol dari sistem informasi perikanan tangkap TCT di Natuna.

\section{Perancangan Sistem Informasi}

Tahap perancangan ini adalah mendesain suatu proses dihasilkannya informasi yang terdiri dari proses pemasukan data yang tersedia ke dalam sistem dari website, pengolahan data dan proses penyajian data. Pada tahap ini digunakan MySQL untuk mengelola ataupun menyimpan database yang telah dimasukan Menurut Triamarsiah \& Arafat (2017), MySQL adalah suatu software yang digunakan untuk membuat basis data yang bersifat open source.Informasi akan dihasilkan dengan memanfaatkan data yang telah diolah dan tersimpan pada database tersebut.

\section{Implementasi Sistem Informasi}

Tahap ini meliputi coding, pembuatan template web, dan hosting domain. Program aplikasi dirancang menggunakan bahasa pemograman Hipertext Prepocessor (PHP) dengan menggunakan framework Laravel untuk pengolahan dan penyimpanan data menggunakan MySQL. Penggunaan PHP dalam pembuatan aplikasi berbasis web ini memiliki keunggulan yaitu dapat memanipulasi sebuah basis data dengan mudah (Supaartagorn, 2011).

\section{Validasi Sistem Informasi}

Tahap ini dilakukan pengujian terhadap sistem informasi yang telah disusun. Validasi dilakukan melalui pengujian dan penyediaan bukti objektif bahwa sistem yang telah dibuat, dibangun dengan proses-proses yang telah benar sesuai karakteristik yang telah ditetapkan. Proses validasi dilakukan dengan dua tahap. Tahap pertama dilakukan pengujian dan pengecekan alur sistem secara keseluruhan.

Tahap kedua dilakukan pengecekan dengan sampel data dan dilakukan penelusuran untuk menentukan sistem informasi yang telah dibuat sudah benar dan beroperasi dengan logika sistem informasi yang tepat. Pengecekan dilakukan dengan melakukan verifikasi data yang dimasukan ke dalam database dengan data yang dicatat nelayan ke dalam logbook hasil tangkapan. Logbook hasil tangkapan diisi oleh nelayan secara manual yang kemudian dimasukan ke dalam sistem database oleh peneliti. Data yang dihasilkan dari pengisian logbook kemudian dijadikan sebagai bahan verifikasi dan back up dari data yang dimasukan ke dalam sistem database.

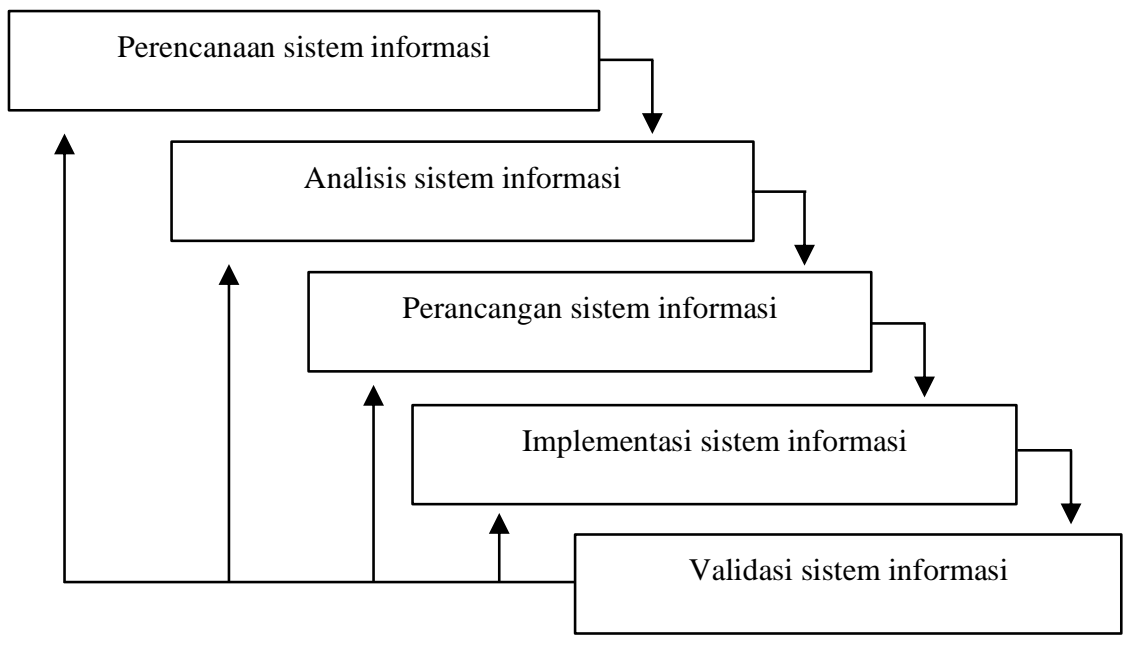

Gambar 1 Metode pengembangan sistem.

(Sumber : Handoyo, 2011) 


\section{HASIL DAN PEMBAHASAN}

\section{Kondisi Perikanan Natuna}

Laut Natuna yang termasuk ke dalam perairan WPP 711 memiliki potensi perikanan yang sangat besar. Adanya potensi perikanan yang besar mendorong masyarakat Natuna untuk menggantungkan hidup pada sektor perikanan tangkap. Menurut DKP Natuna (2019) terdapat 14.325 nelayan di Natuna. Terdapat pertumbuhan jumlah nelayan pada kategori nelayan sambilan utama dan nelayan sambilan tambahan dibandingkan tahun 2018. Kategori nelayan sambilan utama mengalami pertumbuhan sebesar $13,6 \%$, sedangkan nelayan sambilan tambahan mengalami pertumbuhan sebesar $6,074 \%$. Keberadaan nelayan yang relatif besar telah berdampak terhadap pemanfaatan sumber daya perikanan. Berdasarkan data dari DKP Kabupaten Natuna, Laut Natuna pada tahun 2019 memiliki produksi perikanan sebesar 104.879,81 ribu ton, yang didominasi oleh ikan pelagis kecil dan ikan karang.

Produksi ikan yang dihasilkan dari kegiatan penangkapan ikan di Laut Natuna yang didominasi oleh kapal berukuran 0-5 GT. Jumlah kapal perikanan dengan ukuran 0-5 GT pada tahun 2019 mencapai $60,1 \%$ dari total kapal perikanan yang tersebar di Natuna dengan total 2543 unit kapal. Perkembangan kapal perikanan Natuna tergolong masih lambat dengan nilai pertumbuhan $0 \%$ per tahun pada kapal ukuran $5 \mathrm{GT}-10 \mathrm{GT}, 0 \%$ per tahun pada kapal ukuran $10 \mathrm{GT}-20 \mathrm{GT}, 50 \%$ per tahun pada kapal ukuran 20 GT - 30 GT, dan 0\% per tahun pada kapal ukuran lebih dari 30 GT. Pertumbuhan kapal perikanan yang lambat diakibatkan oleh terbatasnya investasi yang dimiliki nelayan. Menurut Zulham et al. (2017) 50\% nelayan yang ada di Bunguran Timur mendapatkan investasi kapal perikanan dari tengkulak atau tauke dan hanya $13,3 \%$ yang menggunakan investasi sendiri.

Nelayan Natuna memiliki budaya yang sangat berpengaruh terhadap kelestarian sumber daya perikanan laut. Tradisi seperti upacara adat dan sedekah laut yang masih rutin dilakukan oleh nelayan Natuna secara tidak langsung telah meningkatkan kepedulian masyarakat terhadap kelestarian sumber daya ikan dan laut. Selain itu kebiasaan nelayan Natuna yang hanya menggunakan alat tangkap tradisional yang ramah lingkungan, berdampak positif terhadap perkembangan sumber daya ikan yang seimbang dengan tingkat pemanfaatannya. Alat tangkap yang digunakan nelayan Natuna didominasi dengan bubu ikan, pancing ulur dan pancing tonda. Jumlah alat tangkap bubu pada tahun 2019 mencapai 21.290 unit, yang terdiri dari bubu ikan sebesar 11.602 dan bubu kepiting sebesar 9.688 unit. Selain bubu alat tangkap yang banyak digunakan oleh nelayan Natuna adalah pancing ulur dan pancing tonda. Jumlah pancing ulur di Natuna mencapai 3.352 unit pada tahun 2019 disusul pancing tonda dengan jumlah 2.658 unit (DKP Natuna, 2019).
Keberadaan tauke sangat penting bagi nelayan tradisional Natuna (Nugroho, 2018). Sebagian besar nelayan tradisional Natuna mendapatkan modal dari tauke. Modal yang diberikan tauke kepada nelayan berupa armada penangkapan, alat tangkap dan perbekalan. Sebelum melakukan kegiatan penangkapan biasanya tauke akan menemui nelayan dan memberikan segala kebutuhan nelayan untuk kegiatan melaut. Setelah nelayan kembali ke dermaga, tauke akan menghampiri nelayan ke dermaga pendaratan ikan dan membeli hasil tangkapan nelayan. Harga yang ditawarkan tauke didasarkan pada harga pasar, sehingga ketika ketersediaan ikan hasil tangkapan tinggi maka tauke akan membeli ikan dengan harga lebih murah dibandingkan pada saat ketersediaan ikan hasil tangkapan rendah. Hal seperti ini yang membuat nelayan merasa nyaman bekerja untuk tauke, di samping modal yang selalu tersedia, nelayan juga mendapatkan kemudahan dalam menjual ikan dengan harga yang baik.

Tradisi nelayan tradisional Natuna yang menjual ikan hasil tangkapan kepada tauke menyebabkan nelayan lebih memilih mendaratkan ikan di tempat yang dekat dengan rumah nelayan. Hal ini menjadi sebab adanya dermaga-dermaga pendaratan ikan disetiap desa di Natuna. Hingga tahun 2019 telah dibangun 86 dermaga yang tersebar di 64 desa. Dermaga tersebut umumnya dibangun dengan swadaya masyarakat dan didukung oleh Anggaran Pendapatan Belanja Daerah (APBD). Konstruksi dermaga yang dibangun umumnya terbuat dari kayu dan beton dengan ukuran tidak terlalu besar.

\section{Pendataan Hasil Tangkapan Ikan di Dermaga Bunguran Timur}

Terdapat tujuh buah tempat pendaratan ikan yang tersebar di Kecamatan Bunguran Timur. Tujuh tempat pendaratan ikan tersebut adalah dermaga Pasar Ranai, dermaga Batu Hitam, dermaga Jemengan, dermaga pelabuhan Penagi, dermaga pelabuhan Pring, dermaga Sungai Ulu, dan dermaga Sepempang. Aktivitas pendataan hasil tangkapan masih jarang ditemui di dermaga-dermaga pendaratan ikan di Natuna. Pendataan hasil tangkapan hanya ditemui di pelabuhan Sentra Kelautan Perikanan Terpadu (SKPT) yang terletak di Selat Lampa.

Pelabuhan SKPT telah melakukan pendataan hasil tangkapan dengan baik. Pendataan dilakukan dengan pengisian logbook oleh petugas pendataan berdasarkan hasil wawancara nelayan pada saat pembongkaran ikan. Berbeda dengan pelabuhan SKPT, di setiap dermaga yang tersebar di Bunguran Timur aktivitas pendataan ikan hasil tangkapan tidak ditemui di setiap waktu. Hal ini dikarenakan metode pendataan yang digunakan berupa metode sampling yang dilakukan pada waktu-waktu tertentu. Perbandingan mekanisme pendataan hasil tangkapan ikan yang dilakukan oleh petugas pendataan hasil tangkapan kabupaten dengan petugas pendataan di SKPT dapat dilihat pada Tabel 1 . 
Tabel 1 Perbandingan pendataan kabupaten dan pusat.

\begin{tabular}{llll}
\hline \multicolumn{1}{c}{ Perbedaan } & \multicolumn{1}{c}{ Kabupaten } & \multicolumn{1}{c}{ Pusat } \\
\hline Tahun & 2014-2015 & 2016-2019 & 2017-2019 \\
Pelaksana & UPTD & PPT & Petugas pencatat hasil tangkapan \\
Metode & Sampling & Sensus dan sampling & Sensus harian \\
Periode & Bulanan, tahunan & Bulanan, tahunan & Harian, mingguan, bulanan, tahunan \\
Sumber & Nelayan & Nelayan & Nelayan, pengepul, Perindo \\
Tempat & Dermaga & Dermaga & Dermaga SKPT, Dermaga sekitar SKPT, dan \\
& & & Perindo \\
\hline
\end{tabular}

(Sumber : Data olahan peneliti)

Petugas pelaksana pendataan hasil tangkapan ikan di Natuna dibagi menjadi dua yaitu Unit Petugas Teknis Daerah (UPTD) pada tahun 2014 hingga 2015 dan Petugas Pelaksana Teknis dari kecamatan pada tahun 2016 hingga 2019. UPTD adalah unit pelaksana teknis yang bertugas melaksanakan kewenangan Provinsi di wilayah Kabupaten. Berdasarkan Undangundang nomor 23 tahun 2014 tentang Pemerintah Daerah yang menarik kewenangan atas laut 0-4 mil dari kabupaten menjadi kewenangan provinsi mengakibatkan adanya kewajiban provinsi untuk ikut melakukan pendataan hasil tangakap ikan di Kabupaten Natuna. Oleh karena itu, UPTD sebagai perwakilan dari provinsi pada tahun 2014 hingga 2015 melakukan pendataan di dermaga-dermaga kecil Natuna. UPTD menggunakan teknik sampling dalam menentukan jumlah hasil tangkapan. Sampling dilakukan satu kali dalam sebulan, dimana hasil sampling dianggap telah mewakili hasil tangkapan dalam sebulan. Teknik sampling digunakan disebabkan kurangnya petugas UPTD, dimana petugas UPTD yang melakukan pendataan hasil tangkapan hanya berjumlah dua orang. Teknik pendataan hasil tangkapan dengan sistem sampling tidak menghasilkan data yang akurat, sehingga hasil pendataan yang dihasilkan dari sampling bukanlah hasil ikan yang didaratkan sesungguhnya.

Setelah UPTD dianggap tidak menghasilkan data hasil tangkapan yang akurat maka pendataan hasil tangkapan dilimpahkan kepada Petugas Pelaksana Teknis (PPT) di masing-masing kecamatan di Natuna. Terdapat setidaknya dua petugas PPT di setiap kecamatan di Natuna. Jumlah petugas yang semakin banyak diharapkan mampu memberikan data hasil tangkapan yang lebih akurat. PPT dalam melakukan pendataan hasil tangkapan menggunakan teknik sensus, dimana petugas mencatat hasil tangkapan di setiap kapal yang mendaratkan ikan di dermaga. Namun pendataan hasil tangkapan dengan metode sensus tidak dilakukan secara kontinyu, dikarenakan jumlah petugas yang masih belum bisa memenuhi kebutuhan.Selanjutnya, Teknik yang digunakan dalam pendataan hasil tangkapan adalah sampling, dimana petugas akan melakukan pendataan di setiap dermaga satu kali dalam satu bulan. Kemudian hasil pendataan satu hari dalam satu bulan dikalikan dengan trip kapal tersebut dalam satu bulan untuk mendapatkan jumlah hasil tangkapan ikan dalam satu bulan. Teknik pendataan yang seperti ini masih menghasilkan data yang kurang tepat. Hal tersebut dikarenakan hasil tangkapan ikan yang didaratkan memiliki jumlah yang tidak sama setiap trip-nya. Teknik pendataan yang tepat adalah teknik yang digunakan oleh SKPT, dimana petugas pendataan akan langsung mencatat setiap ikan hasil tangkapan yang didaratkan di SKPT.

\section{Perbandingan Hasil Pendataan TCT oleh DKP Natuna dan Sistem NKHK}

Perbandingan hasil pendataan Dinas Kelautan dan Perikanan (DKP) Natuna dan sistem Nelayanku Heroku (NKHK) dimaksudkan untuk menilai keakuratan data. Pendataan ikan hasil tangkapan yang dilakukan oleh petugas Dinas Kelautan dan Perikanan di Natuna adalah dengan mekanisme wawancara kepada nelayan, bukan melakukan perhitungan jumlah hasil tangkapan secara langsung ketika nelayan mendaratkan ikan di dermaga. Metode yang digunakan DKP Natuna merupakan metode sampling, dimana pendataan tidak dilakukan disetiap nelayan mendaratkan ikan, namun hanya dilakukan pada saatsaat tertentu. Sedangkan pendataan oleh peneliti yang selanjutnya dibuat sistem Nelayanku Heroku (NKHK) dilakukan langsung saat nelayan melakukan proses pendaratan hasil tangkapan dan dilakukan setiap saat ketika nelayan mendaratkan ikan. Hasil pendataan ikan khususnya jenis tuna, cakalang dan tongkol pada sistem pendataan hasil tangkapan ikan berbasis web NKHK berbeda dengan hasil pendataan yang dilakukan oleh Dinas Kelautan dan Perikanan Natuna.

Data yang diperoleh melalui pendataan NKHK membagi jumlah tangkapan tongkol per spesies tongkol, sedangkan pendataan yang dilakukan oleh Dinas Kelautan dan Perikanan Natuna tidak melakukan pendataan per spesies tongkol. Selain itu ikan cakalang dan tuna yang juga disebut tongkol oleh masyarakat Natuna menyebabkan pendataan ikan cakalang dan tuna oleh dinas dikategorikan juga sebagai ikan tongkol. Harga per kilogram ikan tongkol dalam pendataan melalui sistem NKHK juga bergantung pada spesies ikan tongkol, sedangkan pendataan oleh DKP Natuna menggunakan harga per kilogram ikan tongkol yang dominan. Pendataan harga ikan tongkol yang tidak berdasarkan spesies ikan tongkol akan menyebabkan data nilai produksi yang dihasilkan dari sistem pendataan DKP Natuna bukanlah nilai produksi sesungguhnya. 


\section{Perancangan Sistem Informasi}

A) Rancangan sistem informasi

Rancangan sistem dilakukan untuk menentukan sebuah desain website yang akan dibuat dan menentukan alur dari masing-masing proses komponen dan peran dari masing komponen yang ada pada sistem. Perancangan diagram blok metode untuk menggambarkan peran dari masing-masing komponen yang ada dalam suatu sistem. Diagram blok pada sistem NKHK dapat dilihat pada Gambar 2.

Berikut merupakan peran masing-masing elemen dari sistem informasi pendataan hasil tangkapan NKHK :

\section{Administrator}

Administrator memiliki peran untuk mengatur seluruh proses pengelolaan sistem informasi. Administrator memiliki izin untuk mengakses dan memodifikasi sistem serta bertanggung jawab memantau kinerja sistem. Administrator memiliki hak untuk mengatur semua akses user untuk masuk ke dalam sistem.

2. User

User merupakan pengguna sistem pendataan hasil tangkapan di Natuna untuk memasukan data ke dalam database dan mengambil data dari database.

3. Data

Data merupakan sumber informasi yang dimasukan ke dalam sistem ini. Data yang telah dimasukan kemudian diproses dan dikirim ke database, selanjutnya akan diolah oleh sistem menjadi informasi yang dapat digunakan oleh user.

4. Sistem database NKHK

Sistem NKHK merupakan sebuah sistem berbasis website yang digunakan sebagai tempat untuk memasukan data dan menampilkan informasi dari data yang sudah diolah. Segala aktifitas input data dan pengambilan data oleh user maupun administrator terjadi melalui sistem ini.

\section{Database}

Database yaitu tempat terakhir data yang telah dimasukan tersimpan. Database merupakan komponen penting dalam sistem ini, karena database bertugas menyimpan data dan memilah data berdasarkan kriteri tertentu sehingga mudah untuk diolah.

6. Informasi

Informasi merupakan data yang telah diolah oleh sistem dan kemudian dapat digunakan oleh user.

B) Implementasi sistem informasi

Aplikasi berbasis website perikanan Natuna dengan nama Nelayanku Heroku (NKHK) adalah suatu website basis data yang digunakan untuk melakukan proses pendataan hasil tangkapan secara online. NKHK dibuat untuk memudahkan proses pendataan dan pengambilan data hasil tangkapan di perairan Natuna. NKHK dirancang menggunakan bahasa pemograman Hipertext Prepoccesor (PHP) dengan framework Laravel. Menurut Hanggara (2012), PHP adalah bahasa pemograman server-side yang dirancang untuk dapat digunakan dalam pembuatan aplikasi berbasis website. Sedangkan untuk pengolahan data dan penyimpanan data menggunakan database yang disediakan oleh MySQL.

Implementasi perencanaan sistem dapat dilihat melalui tampilan antar muka dari setiap menu yang ada pada sistem NKHK. Tampilan form login yang harus diisi agar dapat mengakses fitur sistem dapat dilihat pada Gambar 3. Tampilan menu pendataan nelayan yang berisi nama, umur dan jenis nelayan dapat dilihat pada Gambar 4. Tampilan menu pendataan hasil tangkapan ikan dapat dilihat pada Gambar 5. Data yang berhasil dimasukan ke dalam sistem akan diolah menjadi data dalam format Ms. Excel, dan dapat diunduh. Tampilan data yang dapat diunduh dapat dilihat pada Gambar 6.

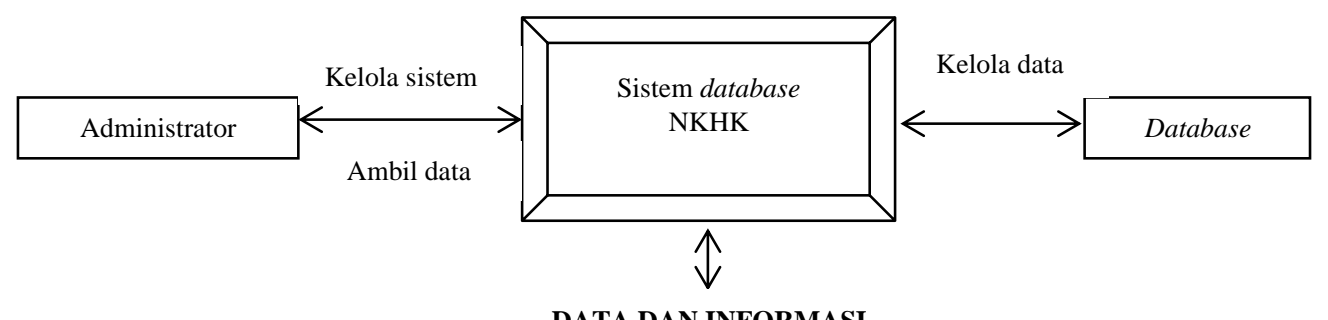

DATA DAN INFORMASI

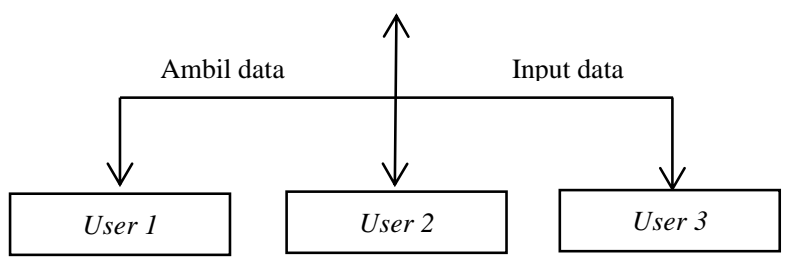

Gambar 2 Diagram blok sistem.

(Sumber : Kajian dari peneliti) 


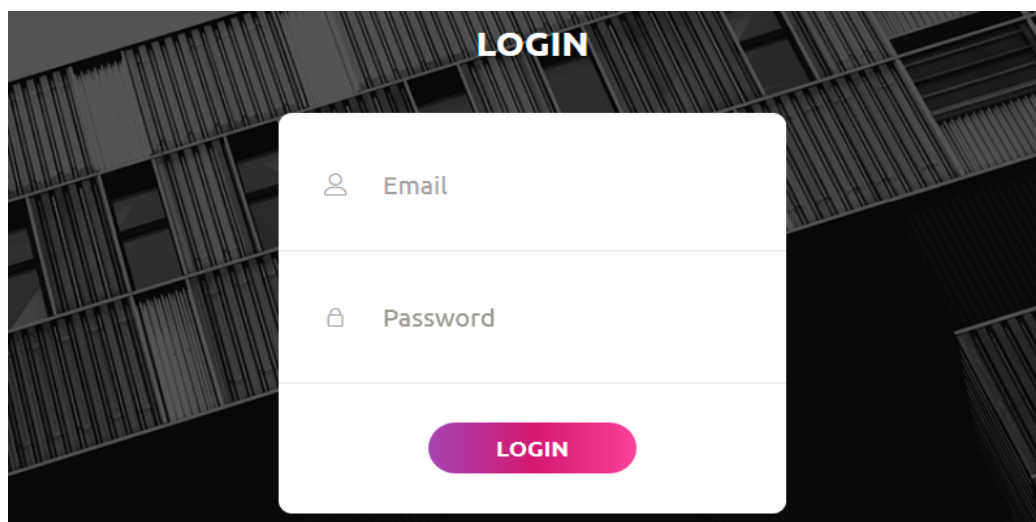

Gambar 3 Tampilan form login

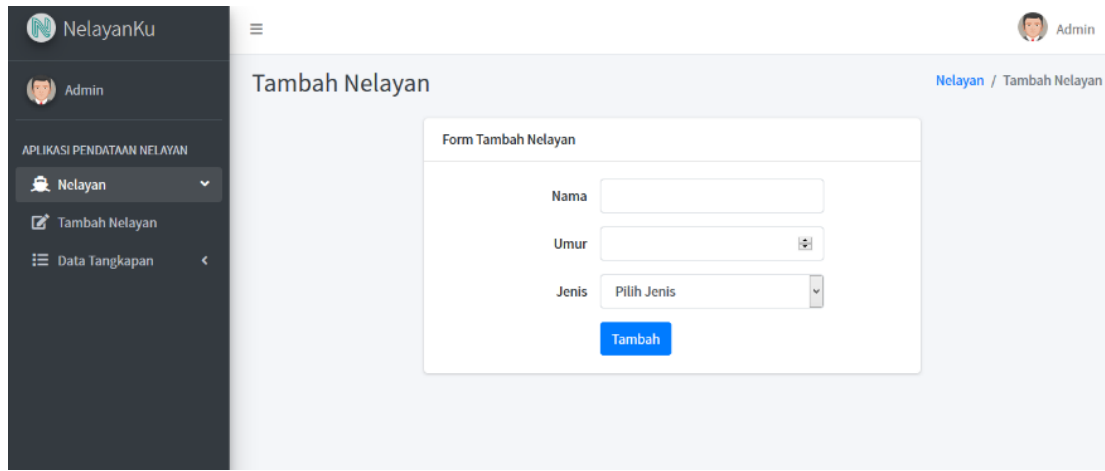

Gambar 4 Tampilan menu pendataan nelayan.

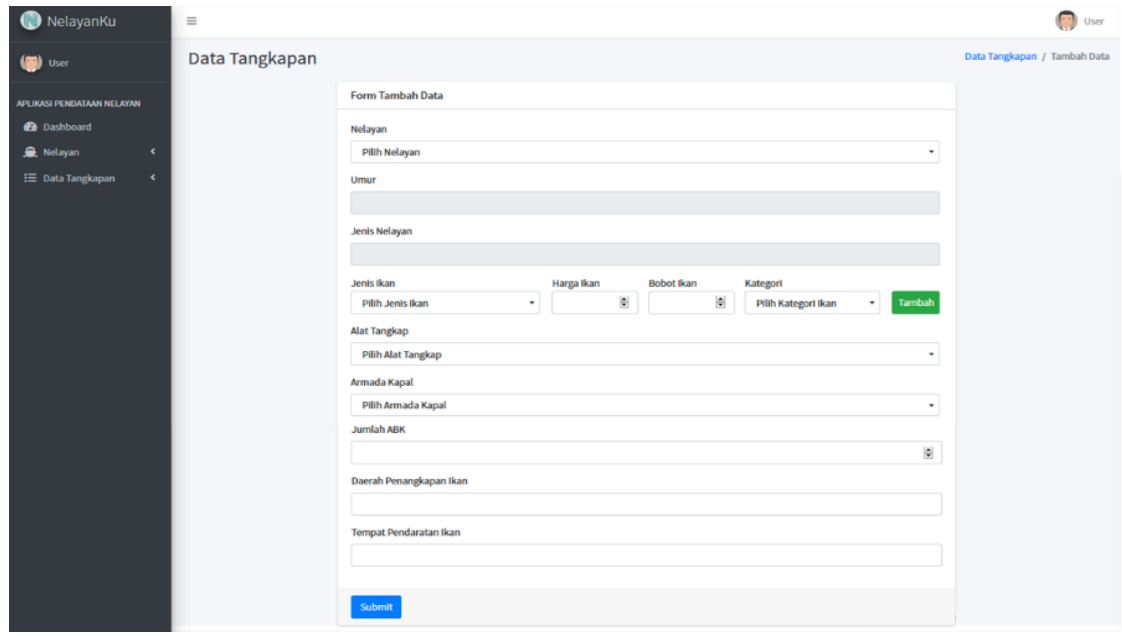

Gambar 5 Tampilan menu pendataan hasil tangkapan ikan.

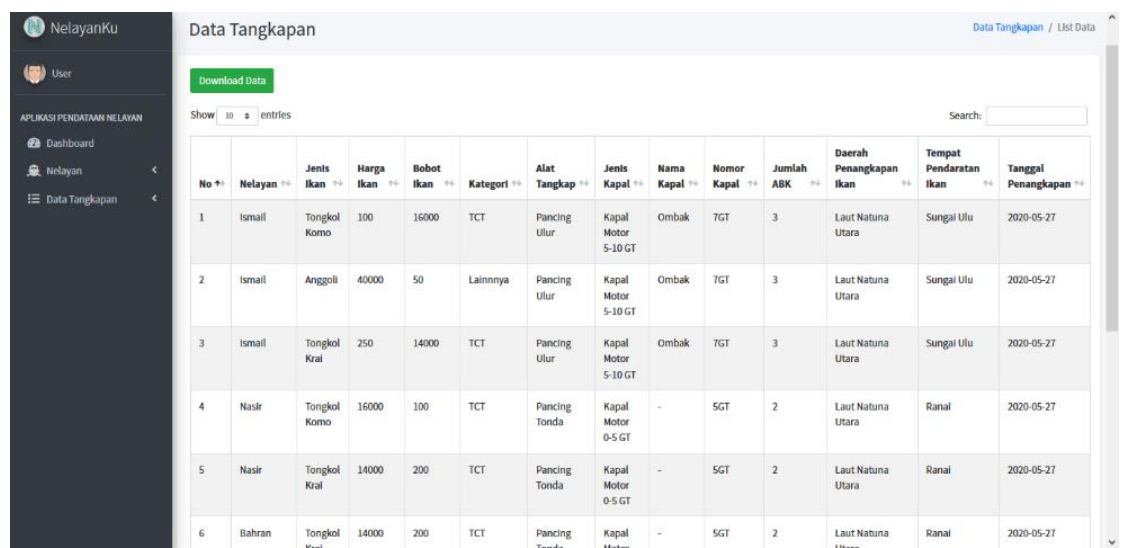

Gambar 6 Tampilan antar muka data yang dapat diunduh. 


\section{C) Validasi Sistem Informasi}

Validasi sistem informasi merupakan tahap pengujian sistem yang telah disusun. Pengujian sistem dilakukan untuk menentukan apakah sistem yang telah disusun telah sesuai dengan spesifikasi sistem dan berjalan di lingkungan yang diinginkan (Muntihana, 2017). Metode yang digunakan dalam pengujian adalah black box testing. Menurut Cholifah et al. (2018) pengujian black box adalah suatu pengujian sistem perangkat lunak dari segi spesifikasi fungsional tanpa pengujian terhadap desain dan kode program. Pengujian black box pada sistem pendataan NKHK menggunakan data lapangan berupa data hasil tangkapan di dermaga pendaratan ikan yang ada di Bunguran Timur. Data hasil tangkapan nelayan di tujuh dermaga yang ada di Bunguran Timur kemudian dimasukan peneliti ke dalam basis data menggunakan sistem pendataan NKHK. Berdasarkan pengujian black box, semua skenario pengujian berhasil dijalankan sesuai dengan hasil yang diharapkan.

\section{Kesiapan Petugas dan Nelayan dalam Implementasi Sistem Informasi NKHK}

Kesiapan petugas dan nelayan dilihat berdasarkan hasil kuisioner yang telah diisi oleh petugas dan nelayan di Bunguran Timur. Kuisioner terdiri atas 4 pertanyaan, yaitu ketersediaan mengisi logbook, kepemilikan gawai, kemampuan baca dan tulis serta kemampuan dalam mengakses website. Pertanyaan tersebut dijadikan dasar dalam menilai kesiapan petugas dan nelayan dalam implementasi sistem informasi NKHK.

Selain kesiapan petugas pendataan, kesiapan nelayan juga sangat penting. Apabila kesiapan nelayan dinilai baik maka nelayan dapat mendata hasil tangkapan melalui gawai pribadi yang mereka punya, namun apabila kesiapan nelayan dinilai masih kurang maka pendataan hasil tangkapan tetap harus dilakukan oleh petugas pendataan hasil tangkapan di setiap kecamatan.

1. Kesiapan Petugas Pendataan Hasil Tangkapan Berdasarkan hasil kuisioner terdapat 100\% responden memiliki kesiapan dalam semua kriteria. Artinya bahwa semua responden yang merupakan petugas pendataan hasil tangkapan di Bunguran Timur memiliki kesiapan untuk mengimplementasikan sistem informasi NKHK dengan baik.

2. Kesiapan Nelayan

Berdasarkan hasil kuisioner yang diisi oleh nelayan di Bunguran Timur, hanya terdapat 13\% responden bersedia mengisi logbook. Jumlah responden yang bersedia mengisi logbook sangat sedikit dikarenakan hampir semua nelayan memiliki tauke, sehingga nelayan memiliki ketakutan apabila harus mengisi logbook tanpa izin dari tauke. Selanjutnya hanya $23 \%$ dari total responden yang memiliki gawai. Umumnya nelayan hanya menggunakan handphone biasa, sekadar untuk melakukan panggilan ataupun pesan singkat. Terdapat $90 \%$ dari total responden yang memiliki kemampuan baca dan tulis serta hanya $19 \%$ responden memiliki kemampuan dalam mengakses website. Kemampuan mengakses website sangat berkaitan dengan kepemilikan gawai. Kurangnya penggunaan gawai oleh nelayan menyebabkan kemampuan dalam mengakses website juga terbatas.

\section{SIMPULAN}

Terdapat 7 dermaga pendaratan ikan yang tersebar di Kecamatan Bunguran Timur. Dermaga di Bunguran Timur umumnya memiliki kondisi yang baik dengan kontruksi semi permanen hingga permanen. Saat ini pendataan hasil tangkapan di dermaga dilakukan melalu metode sampling. Sampling dilakukan setiap bulan sekali dengan jumlah petugas dua orang di setiap kecamatan. Berdasarkan metode yang dilakukan saat ini, maka data yang didapatkan kurang akurat dibandingkan dengan mekanisme pendataan yang dilakukan di SKPT yaitu dengan metode sensus. Penggunaan sistem NKHK untuk melakukan pendataan dapat meningkatkan keakuratan data. Pendataan dengan sistem NKHK dilakukan setiap hari di setiap dermaga dengan dua orang petugas disetiap kecamatan. Hasil data yang langsung dapat diunduh dalam format Ms. Excel dapat mengefisiensikan waktu dalam pengumpulan dan pengolahan data. Petugas pendataan hasil tangkapan ikan di Bunguran Timur memiliki kesiapan implementasi sistem NKHK dengan baik, yaitu memenuhi kriteria kesiapan dalam kepemilikan gawai, kemampuan baca dan tulis, kemampuan dalam mengakses website dan ketersediaan dalam mengisi logbook.

\section{DAFTAR PUSTAKA}

Andrasto T. (2013). Pengembangan Sistem Database Hasil Penelitian dan Pengabdian Kepada Masyarakat Dosen Unnes. Jurnal Teknik Elektro, 5, (2), 65-69.

[BPS] Badan Pusat Statistik Kabupaten Natuna. (2017). Kabupaten Natuna dalam Angka 2017. Ranai: BPS Kabupaten Natuna.

Cholifah WN, Yulianingsih \& Sagita SM. (2018). Pengujian Black-Box Testing pada Aplikasi Action \& Strategy Berbasis Android dengan Teknologi Phonegap. Jurnal String, 3, (2), 206-210.

[DKP] Dinas Kelautan dan Perikanan Kabupaten Natuna. (2018). Laporan Tahunan Dinas Kelautan dan Perikanan Kabupaten Natuna Tahun 2018. Ranai: DKP Kabupaten Natuna.

[DKP] Dinas Kelautan dan Perikanan Kabupaten Natuna. (2019). Laporan Tahunan Dinas Kelautan dan Perikanan Kabupaten Natuna Tahun 2019. Ranai: DKP Kabupaten Natuna.

Handoyo K. (2011). Sistem Informasi Pengelolaan Sumberdaya dan Lingkungan Perikanan Tangkap di Kabupaten Padang Pariaman, Sumatera Barat. Skripsi. Institut Pertanian Bogor. 
Hanggara Y. (2012). Analisis Sistem Informasi Pengelolaan Data Alumni Sekolah Berbasis Codeigniter PHP Framework. Skripsi. Universitas Negeri Yogyakarta.

Ismail K, Kusasi F \& Fitria R. (2018). Perikanan Natuna dan Kesejahteraan Nelayan Pasca Penerapan Kebijakan IUU Fishing. Jakarta: Indonesian Marine Fellows Program.

Juliandi A, Irfan \& Manarung S. (2014). Metodologi Penelitian Bisnis: Konsep dan Aplikasi. Medan: UMSU Press.

[KKP] Kementerian Kelautan dan Perikanan. (2016). Kelautan dan Perikanan dalam Angka Kabupaten Natuna. Jakarta: KKP.

[KKP] Kementrian Kelautan dan Perikanan. (2019). Laporan Kinerja Pusat Data, Statistik, dan Informasi Triwulan II 2019. Jakarta: KKP.

Muntihana V. (2017). Analisis dan Perancangan Sistem Informasi Berbasis Web dan Android pada Klinik Gigi Lisda Medica di Kabupaten Bulukumba Sulawesi Selatan. Skripsi. UIN Alauddin Makasar.

Nugroho T. 2018. Kebijakan Pembangunan Kelautan dan Perikanan Indonesia. Yogyakarta: Plantaxia.

Pemerintah Republik Indonesia. 2014. UndangUndang Republik Indonesia Nomor 23 Tahun 2014 Tentang Pemerintahan Daerah. Jakarta: Sekretariat Negara.

Pemerintah Republik Indonesia. 2014. UndangUndang Republik Indonesia Nomor 23 Tahun 2014 Tentang Pemerintahan Daerah. Jakarta: Sekretariat Negara.
Pradipta S. (2010). Sistem Informasi Manajemen Agribisnis Perikanan Tangkap di PPI Blanakan, Kabupaten Subang, Jawa Barat. Skripsi. Institut Pertanian Bogor.

Presiden Republik Indonesia. 2016. Instruksi Presiden Republik Indonesia Nomor 7 Tahun 2016 Tentang Percepatan Pembangunan Industri Perikanan Nasional. Jakarta: Sekretariat Kabinet RI.

Setiawan A, Wibawa F \& Burhanudin A. (2016). Analisis Kebutuhan Sistem Informasi Perwalian Mahasiswa Berbasis Website Studi Kasus Teknik Informatika UM Magelang. Prosiding Konferensi Nasional Sistem Informasi. Batam, 11-13 Agustus 2016. Hal 684-687.

Supaartagorn C. (2011). PHP Framework for Database Management Based on MVC Pattern. International Journal of Computer Science \& Information Technology (IJCSIT), 3, (2), 251258

Triamarsiah Y \& Arafat M. (2017). Analisis dan Perencanaan Website sebagai Sarana Informasi pada Lembaga Bahasa Kewirausahaan dan Komputer AKMI Baturaja. Jurnal Matrix, 9, (1), 3-8

Waljiyanto. (2003). Sistem Basis Data: Analisis dan Pemodelan Data. Yogyakarta: Graha Ilmu.

Zulham A, Subaryono \& Anggrawangsa RF. (2017). Rekomendasi Pengembangan Perikanan Tangkap di Natuna dan Sekitarnya. Depok: PT. Raja Grafindo Persada. 